\title{
Research on the Design Strategy of Micro - course Based on Flipped Classroom
}

\author{
Binbin $Y u^{1, a}$ and Dawei Zhan ${ }^{1, b^{*}}$ \\ ${ }^{1}$ Beihua University, College of Information Technology and Media, China \\ a22342690@qq.com, b125758398@qq.com
}

Keywords: Flip classroom; Micro - course; Teaching evaluation; Micro - course design

\begin{abstract}
The traditional teaching mode, which is mainly taught by teachers, is not conducive to the development of students' subjectivity. The emergence of micro-courses has renewed the educational philosophy, micro-class more focus on learners so that learners learn fragmented learning resources. It may meet the needs of students personalized learning and achieve better teaching effect. This article explains the connotation of micro - course, the method and principle of micro - course resources design based on flipped classroom teaching, how to effectively integrate the flipped class with the micro class, how to design micro - course.
\end{abstract}

\section{Introduction}

Micro-course, which has a complete teaching design, is an important part of the classroom prominent teaching theme and clear teaching objectives. We can pay attention to how to make the teaching video more accurate express the focus and difficulties of knowledge and other problems in the micro-course design, make the teaching objectives refinement and the teaching content rich and innovative in order to become a teaching system. The micro-course is a teaching activity which is characterized by short time, small amount of unit knowledge, well crafted. In the pre-class session, the teacher can create the micro course for a certain knowledge point according to the teaching objectives. In the micro-class students take the initiative to learn teaching content. In the course the teacher can answer and ask questions, guide the students to consolidate and transfer the knowledge.

\section{Micro-course Overview}

Today is the moment which is the era of knowledge and information big bang. While the amount of knowledge and information is increasing rapidly and knowledge updating speed is speeding up, the frontier knowledge of disciplines is constantly updated. Faced with such a volume of knowledge and knowledge update speed, the traditional classroom cannot present the latest knowledge. The traditional classroom teaching model which is the process of new knowledge and new knowledge in class and new knowledge learning for students outside the classroom is reversed by flipped classroom. [1][2]

In the new generation of information technology environment, teachers can use educational technology to obtain and edit text, graphics, images, audio, video and other learning materials so that students learn fragmented and accessible cutting-edge knowledge. It brings learners' instant learning knowledge and satisfaction of learning knowledge. So it is essential that we pay attention to the position of micro-course and flipped classroom.

Micro - course [3], which is online learning using a new generation of information technology, is based on constructivism theory, ubiquitous learning theory and knowledge visualization theory. Knowledge is fragmented and reconstructed by micro - course [4][5]so that each section of the micro-course is the integrated knowledge or teaching links, with independent, representative and independent integrity of the teaching design which Include context introduction, teaching background, teaching objectives, teaching methods, teaching summary and other links. Different scholars have different understanding of micro-course, such as Professor Hu Tiesheng believes that micro-course is an organic combination of various teaching resources used by teaching and learning activities for a certain 
knowledge point. [6] Professor Li Jiahou believes that the teaching objectives of the micro-course which can accurately explain one knowledge point or teaching link are clear, the teaching contents are short. [7]

\section{Design Strategy of Micro - course based on Flipped Classroom}

Design of micro - course based on flipped classroom is not only the text, audio and video production, but learning resources, teaching process design. [8] Micro - course based on flipped classroom which changes the traditional classroom dominated by teachers to new classroom centered on students and assisted by teachers, makes a dramatic change in the role of teachers and students. Micro - course based on flipped classroom combines mobile learning, blended learning, and fragmentation learning and then students free from the limitation of time and space and study at any time and place to improve his knowledge level. It makes classroom teaching more suitable for the need for talent training of society and more conducive to the establishment of life-long learning society.

Teachers Could Precise Select Unit Teaching Content to Form a Content Series. Excellent design and production of micro - course should have the characteristics of accurate teaching objectives, clear teaching content, prominent teaching heavy and difficult, good technical skills and so on. [9]When teachers design and produce for micro-courses, they should choose the appropriate teaching content, appropriate visualization presented in order to achieve better teaching results. [10] Micro - course is characterized by short time, unit teaching knowledge. Although it is a miniature course, it has a complete teaching design. The teaching content is miniaturized, processed and arranged reasonably, and refined so as to form an effective systematic learning content. Each micro curriculum designed by the teacher has certain relevance and practicability, which stimulates the learner's subjective initiative, ensure the micro video meets the teaching rules, meet the teaching objectives, and highlight the focus and difficulty of teaching and then achieve better teaching results.

Teachers Could Select Appropriate Teaching Resources so as to Form a Systematic and Thematic Vide. Teachers can select appropriate teaching resources, such as text, graphics, images, audio, video, etc. They could take the micro-course as the carrier of teaching resources, choose the appropriate teaching resources and teaching content, integrate teaching objectives. It may make the teaching content visual, vivid and efficient to create the learning situation conducive to learners, make the micro-class better serve the teaching so that students get further development. [11]Teachers should continue to improve their own information literacy and use the skilled technology to produce micro-course, which makes the teaching content visualized, vivid and efficient so as to stimulate learners' interest in learning. Teachers should elaborately select the suitable teaching content, carry on a reasonable rational distribution of the knowledge spot, write the script and make the courseware. They can design and product micro-course in accordance with the standards of micro-course in order to realize the systematic and thematic of the micro-course. It makes serial videos better for teaching services. The design of micro video is shown in Fig. 1.

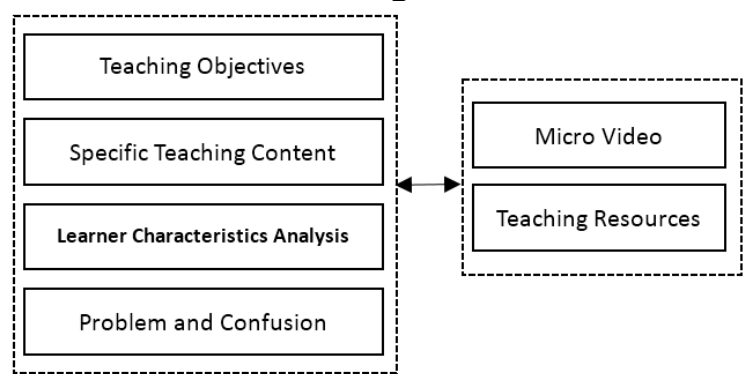

Figure 1. The design of micro video

So the influence of systematic and thematic of the micro-course is essentially positive, it is worthwhile to popularize systematic micro-course. Systematic and specialized teaching content is better service for flip classroom that combined with online and offline teaching model.

Diversified and Integrated Teaching Evaluation Methods. Teaching evaluation [12], which can be divided into formative evaluation and summative evaluation, is the direct effect to monitor the 
teaching process and judge the effect of teaching of every link in the teaching activities. It has the function of promoting and strengthening education and teaching. By the means of teaching evaluation, the teacher grasps the knowledge level that the learner passes the micro-course study for the sake of Meet the actual development of learners. According to the flip classroom teaching situation, the teacher makes a comprehensive evaluation with respect to the students' micro-course learning in order that ensure the scientific evaluation system and standard. By means of interviews and so on, teacher masters the feedback information of students, understands the difficulties encountered by students in the process of learning, and formulates appropriate solutions to problems and effective teaching resources. It will solve many practical problems such as the development needs of students learning to learn.

\section{Micro - course Video Production Methods}

Micro-video whose has highly personality, wide range of applications is the core of micro-course. The quality of micro video production determines the teaching effect of micro-course. According to the teaching link, Micro-course can be divided into pre-class review type, teaching new knowledge type and so on.

Pre-class review based on the students' original cognitive level can develop teaching programs. Teacher may choose not to be photographed or photographed. Teacher who does not leave the photograph can use screen video recording software and multimedia courseware to display teaching content on the computer screen. Others who choose to be photographed in the classroom, micro-classroom, studio, laboratory and other places can use the blackboard, whiteboard, projector, camera, recording system and other teaching equipment for video recording.

The new knowledge instruction type is the learning situation that the teacher creates conforms to the teaching content in accordance with the established teaching design knowledge teaching, through the camera, recording and broadcasting system, software and other recording activities clear procedures. Learners can learn new knowledge without the limitation of time and space.

\section{Summary}

In the process of building the lifelong learning society, learners' learning resources are ubiquitous and the learning styles are more flexible. After mastering the strategy of micro class design, the teacher should make precise orientation of the teaching content and teaching target and then promote development of classroom teaching and flip classroom teaching.

\section{Acknowledgements}

This work is supported by the Society Science Association Planning Project of Jilin Province (Grant 1638-8).

\section{References}

[1] Bin Yang and Yining Wang: China Educational Technology, Vol. 337 (2015) No.2, p. 119-120. (In Chinese)

[2] Yanhong Liu: Continuing Education, Vol. 198 (2012) No.5, p.26-27. (In Chinese)

[3] Shieh: Chronicle of Higher Education, (2009) No.26.12.

[4] Baocong Jiao, Gushan Su and Nan Chen: Modern Distance Education Research, Vol. 138 (2015) No.6, p.89-90. (In Chinese)

[5] Zhimin Chen, Jinjiao Lu, Meifeng Liu: Modern Distance Education Research, Vol. 24 (2014) No.8, p.20-22. (In Chinese)

[6] Fengying Ma: Research on primary school students' media literacy education based on micro-courses (MS., Northeast Normal University, China 2014), p. 8-9. (In Chinese) 
[7] Fengying Ma: Research on primary school students' media literacy education based on micro-courses (MS., Northeast Normal University, China 2014), p. 10-11. (In Chinese)

[8] Tiesheng Hu and Xiaoqing Zhou: Modern Educational Technology, Vol. 24(2014) No.2, p.20-21. (In Chinese)

[9] Xinglong Zhao and Weihua Zhan: Modern Distance Education Research, Vol. 126(2015) No.4, p.54-55. (In Chinese)

[10] Xiangzeng Meng: Journal of Distance Education, Vol. 225 (2014) No.6, p.25-26. (In Chinese)

[11] Huiqin Zhang: Educational Information Technology, (2015) No.7, p.144-145. (In Chinese)

[12] Youru Xie and Kedong Li: Basic Research Methods on Educational Technology (Higher Education Press, China 2006). 